\title{
Accounting for Justice: Citizen Public Debt Audits and the Case of Puerto Rico
}

\author{
WENDY WIEDENHOFT MURPHY \\ John Carroll University, USA
}

\begin{abstract}
A Citizen Public Debt Audit (CPDA) is an emancipatory praxis that can mobilize citizens to make legible public debt that has been accrued in their name. Ideally, it should hold creditors accountable for debt that is determined to be odious. This study examines the public debt crisis in Puerto Rico to illustrate the historically unjust circumstances under which public debt was accumulated on the island in the context of US federal taxation and economic policies. It explains how citizens are mobilizing via a CPDA to make these circumstances legible and argues that citizens should not be obliged to service debt that was accrued contrary to their own welfare, especially if conditions of repayment threaten their current and future well-being.
\end{abstract}

KeYwords citizen public debt audit; Puerto Rico's debt crisis; odious debt; social accounting

\section{Introduction}

Historically, public debt has been a central way that states have financed wars, funded public works, and if managed properly, reinforced political stability (Di Muzio \& Robbins, 2016; Wright, 2008). However, not all political leaders accrue public debt in the interests of their citizens. Corrupt leaders borrow money to finance personal expenditures and secure patronage for elites. International lending institutions, like the World Bank and International Monetary Fund (IMF), offer financially (and often politically) unstable governments loans to fund economic development, but compel them to pay their debts at the expense of the current and future welfare of their citizens. If citizens are not the beneficiaries of public debt and lack the power to determine the conditions of this debt, including what it should be used for and how it should be repaid, then should they be obliged to pay it back? If 
not, how can citizens make legible or account for what they consider unjust public debt?

This article argues that a citizen public debt audit (CPDA) is a valuable tactic to make public debt transparent. As an emancipatory praxis a CPDA empowers citizens with the knowledge of "what and whom is driving debt that is in their name" (Peden, 2019, p. 569). Subsequently, they can use this knowledge to hold political leaders and creditors accountable for public debt that is exposed as unjust and perhaps even odious, demanding that it either be canceled or significantly restructured. The current $\$ 73$ billion public debt crisis in Puerto Rico will be used as a case study to illustrate the unjust circumstances under which public debt can be accumulated and explain how citizens are mobilizing via a CPDA to make these circumstances legible in an attempt to demonstrate why they should not be obliged to service debt that was accrued contrary to their own welfare (Morales, 2019b; PradosRodríguez, 2019; Walsh, 2019). ${ }^{1}$

\section{The Peculiar Nature of Puerto Rico's Public Debt}

Puerto Rico's public debt is complicated due to its past and present colonial status. One of the world's oldest colonies, Puerto Rico was subjected to Spanish rule from 1508 until 1898 when it was acquired by the United States after the Spanish-American War. Puerto Rico officially became an "unincorporated territory" of the United States after the 1901 Insular Cases were decided by the Supreme Court. While the 1900 Foraker Act allowed Puerto Rico to establish its own civilian government, its status as an unincorporated territory meant that full US constitutional rights were not extended to residents on the island. This status also curtailed the ability of self-governance in Puerto Rico because the US government possessed the power to determine internal affairs, creating "insular colonial subalterns" under a system of "political tutelage" (Fusté, 2017, p. 95). The denial of full constitutional rights and limited self-governance continued after Puerto Ricans were granted US citizenship in 1917 (yet were not permitted representation in Congress) and when the island became a US Commonwealth in 1952 (Smith, 2001).

Today, Puerto Rico remains a territory of the US, which constrains the ability of the Puerto Rican government to raise revenue from other means than the sale of government bonds. Since it is not an independent nation-state it cannot obtain loans from the IMF or World Bank or bilateral loans from other countries. The origin of Puerto Rico's public debt is from the sale of municipal bonds, mostly to private creditors from the US mainland (Bannan, 2016). These bonds were declared "triple tax exempt" when Puerto Rico

\footnotetext{
${ }^{1}$ Approximately $\$ 50$ billion is also owed to pensioners.
} 
became a US territory in 1917; therefore, bond holders do not have to pay federal, state, or local taxes on interest. They also do not have to reside in Puerto Rico to take advantage of this exemption. Congress "touted" the triple tax exemption "as a powerful instrument" for permitting its territorial governments, like Puerto Rico, with a way to borrow to fund infrastructure instead of creating a sustainable budget (Fusté, 2017, p. 104). This shaped the island's dependency on borrowing almost from Puerto Rico's inception and set a precedent for the government to sell bonds in order to balance its budget and finance public works and services. Additionally, a stipulation in Puerto Rico's constitution that requires general obligation (GO) debt be paid before any other debt (and by any means necessary) was a nod to creditors that their welfare would receive priority over ordinary citizens $(\mathrm{Ho}, 2018){ }^{2}$ The triple tax exemption and constitutional prioritization of GO debt payment has made Puerto Rican bonds enticing to investors and encouraged Puerto Rico to keep borrowing money instead of discovering other ways to raise revenue, such as imposing higher corporate taxes or income and property taxes on the island's elite (Ko, 2018).

Puerto Rico's public debt is further complicated by the fact that it is not a US state, so it cannot permit its municipalities to file for Chapter 9 bankruptcy. A 1984 law passed by Congress (and upheld by the US Supreme Court in 2016) prohibits Puerto Rico from claiming the status of a state "for the purposes of defining who may be a debtor" (Ko, 2018, p. 3191; emphasis in original). This bankruptcy exclusion restricts Puerto Rico from attempting to restructure or possibly eliminate its debt and favors the power of its bond holders to sue to recoup their investments in district courts (Ko, 2018). Confronted with a shrinking tax base due to deindustrialization and outmigration and lacking the agency to file for Chapter 9 bankruptcy or obtain loans from any other source than selling municipal bonds, the governor of Puerto Rico announced in 2015 that the island's debt was "not payable" and Puerto Rico defaulted on some of its $\$ 73$ billion public debt shortly thereafter. This prompted Congress to pass the Puerto Rico Oversight, Management, and Economic Stability Act (PROMESA) in September 2016, which placed a temporary "stay" on any potential default litigation by Puerto Rico's creditors and suspended debt payments. PROMESA established the Financial Oversight and Management Board (FOMB) to restructure Puerto Rico's debt and manage its budget; it has the power to implement a variety of austerity measures, such as selling state assets and requiring hiring freezes in the public sector. Locally referred to as la Junta, FOMB consists of seven members appointed by the US President and Congress. Only one member is required to have primary residency or a principal business in Puerto Rico. In

\footnotetext{
${ }^{2}$ Puerto Rico has two types of debt: GO and Corporación del Fondo de Interés Apremiante (COFINA) debt. COFINA debt consists of revenue bonds that are paid from the island's $11.5 \%$ sales tax (Ho, 2018). CONFINA debt is owned primarily by hedge and vulture funds (Morales, 2016). Both types of bonds were deemed relatively risk free by investors because their repayments could be secured by the Puerto Rican government via taxation or selling state assets.
} 
short, FOMB is "immune from review by the government of Puerto Rico, including its courts," which is one reason its critics argue that it is "a stark reminder of the island's colonial status" (Weiss \& Setser, 2019, p. 163) if not a manifestation of neocolonialism (Selbst, 2016).

Indeed, Puerto Rico's ascendency into a “debt state" (Streeck, 2014) certainly exemplifies Di Muzio and Robbins' (2016) definition of neocolonialism as a "system of indirect domination that cedes political independence in order to preserve economic dependence and exploitation" ( $p$. 77). Less than $20 \%$ of the island's debt is owned by Puerto Ricans and only $\$ 67$ million of $\$ 100$ million in taxed corporate earnings remain on the island, creating a loss of wealth and accompanying need for more government borrowing (Morales, 2016). Over the years US economic and tax policies have served economic interests on the mainland from agricultural products (especially sugar), to inexpensive labor for the textile industry, to the capitalintensive pharmaceutical industry (Grosfoguel, 2003). Congress passed the 1947 Industrial Incentives Act (commonly referred to as "Operation Bootstrap") that successfully attracted US owned factories, but most finished goods and capital accumulation moved from the island to the mainland, benefiting offshore companies and consumers. Paradoxically, Operation Bootstrap necessitated the Puerto Rican government to borrow funds to invest in power, transport, and water-and-sewer infrastructure, education, and healthcare - all necessary "supplies" needed to support the building, maintenance, and workforce of the factories (Caraballo-Cueto \& Lara, 2018, p. 2; Grosfoguel, 2003). While the residents of Puerto Rico became dependent on precarious manufacturing jobs that began to evaporate once deindustrialization started to occur in the 1990s, the government became further indebted (Caraballo-Cueto \& Lara, 2018).

Deindustrialization in Puerto Rico was prompted by changes in US tax policy and trade liberalization (Caraballo-Cueto \& Lara, 2018; Greenberg \& Ekins, 2015). In 1976 Congress approved US Internal Revenue Code Section 936, which exempted US companies in Puerto Rico from paying federal income taxes and allowed them to repatriate these untaxed profits to the US mainland. However, once Section 936 was repealed in 1996 and phased out entirely in 2006 many of these companies left Puerto Rico and the deindustrialization that followed resulted in unemployment and stagnant economic growth. The island's economic output dropped 14\% between 2004 and 2014 and its cumulative bond debt reached over 100\% of its GNP in 2015. Growing unemployment and soaring debt resulted in massive outmigration: 80,000 people left Puerto Rico between 2014 and 2015. In addition, the devastation wrought by Hurricane Maria in 2017 forced many to leave. Astoundingly, the island's population decreased from 3.8 million in 2008 to less than 3.2 million in 2019 . Equally troublesome is that $45 \%$ of the island's residents that remain live below the federal poverty line (Fusté, 2017; Ko, 2018; Weiss \& Setser, 2019). 
Outmigration from the island contracted Puerto Rico's tax base even further and compelled the government to sell bonds "to anyone who would buy them" (Ko, 2018 p. 316). This resulted in a surge in sales, especially after they were downgraded to junk status in 2014 , when $\$ 3.5$ in billion GO bonds were sold (Ko, 2018; Morales, 2016). Predatory vulture funds circled to purchase these deeply discounted bonds - some for as little as 30 cents on the dollar - with the expectation that even if Puerto Rico defaulted on its debt these funds could likely recoup repayment at a substantially marked up (if not full) value (Lumina, 2018; Morales, 2016). ${ }^{3}$ Not only are hedge funds trying to profit from Puerto Rico's debt crisis, so are other members of the financial elite from the mainland. With an extremely low corporate tax rate of four percent (compared to $21 \%$ on the mainland), Puerto Rico has become a tax haven for many US firms and entrepreneurs (Klein, 2018; Weiss \& Setser, 2019). If they base their business in Puerto Rico, then they do not have to pay taxes on any corporate dividends they earn (Klein, 2018, p. 17). In addition if they move their permanent residency (at least 183 days per year) to Puerto Rico they can also avoid paying personal federal income taxes. These (neo)liberal tax policies have attracted the attention of cryptocurrency entrepreneurs who are hailing Puerto Rico as an experimental utopia for creating their own money - and gated communities (Klein, 2018). While they may pay to use the island's troubled power grid to generate blockchains, they are unlikely to contribute any significant job growth on the island. Past and present tax policies that favor corporate interests are not a judicious solution to Puerto Rico's public debt crisis. It places an unfair if not impractical burden on lifelong residents to service this debt at the same time they are forced to cope with cuts in public services, especially those due to privatization, and pay higher sales taxes as described below. This raises the issue of whether or not some (if not all) of this public debt should be repaid.

\section{Odious and Unjust Debt}

Clearly, the public debt owed by Puerto Rico is unsustainable. The question of whether this debt and its corresponding rate of interest were fairly and legally accrued is the first step in determining if it should be repaid. Public debt is governed by the legal doctrine of pacta sunt servanda (pacts must be repaid). There is no bankruptcy mechanism for public debt, so future generations are responsible to service the debt of past regimes, even those that were despotic or corrupt (Wong, 2012). While lenders may feel secure that public debt can be "serviced by the ever-growing regressive taxation of

\footnotetext{
${ }^{3}$ The vulture fund, Aurelius Capital Management LP, bought a portion of Argentina's defaulted public debt in 2010 and successfully sued the country for full repayment in US courts. This lawsuit obstructed Argentina from finalizing its debt restructuring plan until it was settled in 2016 (Gluzmann et al., 2018) Currently, Aurelius owns a portion of Puerto Rico's debt and is suing the Puerto Rican government for prioritization of its debt repayment (Walsh, 2019).
} 
the public" (Di Muzio \& Robbins, 2016, p. 31), governments are using tax revenue to service debt at the expense of funding public services and paying pensions that benefit citizens. In the case of Puerto Rico FOMB has authorized austerity measures that have privileged debt and interest repayments to bond holders over the basic human rights of Puerto Ricans. Residents are now being forced to endure significant reductions in public services, like education and healthcare, to pay the island's debt. Among other austerity measures FOMB increased the sales tax from seven percent to $11.5 \%$ and lowered the minimum wage from $\$ 7.25$ to $\$ 4.25$ for workers under 25 years old (Bannan, 2016; Morales, 2019b). Even before Congress passed PROMESA 150 schools were closed and public sector jobs were cut in an effort to manage the economic fallout associated with deindustrialization and the corresponding growth of public debt. Unlike US states, the Medicaid program in Puerto Rico is funded via fixed block grants instead of the federal government matching at least one dollar in federal funds for every dollar that states spend, which has left impoverished residents with less funding for healthcare and has encouraged doctors to leave the island for better pay (Torres, 2019). This unequal funding has contributed to the public debt crisis as the Puerto Rican government has had to finance additional healthcare costs with GO and CONIFA revenue at the cost of $\$ 25$ billion (Haddad, 2019; Torres, 2019).

Opponents have had some success contesting pacta sunt servanda with the doctrine of odious debt. Odious debt is defined as debt that is received without the consent of the people and spent in ways contrary to the wellbeing of the people with the further stipulation that creditors are cognizant of these practices (Boyce \& Ndikumana, 2012; Wong, 2012). Using the doctrine of odious debt can allow states that accrued debt under a dictatorship, for example, to make the claim that the debt was not contracted in good faith and is therefore not transferable to "the people." The first application of the odious debt doctrine occurred after the Spanish-American War in 1898 when the United States declared that the debt owed to Spain by the territories it acquired, including Cuba, the Philippines, and Puerto Rico, should not be paid because it was not accrued by their consent nor did it benefit them (Bannan, 2016; Brown, 2015). More recently, Ecuador invoked the doctrine in 2008 to repudiate external debt that it found to be illegitimate due to "unfair gains to private interests, oppressive terms in the bond contracts, and the fact that the country's debt burden was crowding out provision of basic public goods and services" (Feibelman, 2017, p. 48). ${ }^{4}$ Though the doctrine gained popularity after the Bush administration considered applying it to

\footnotetext{
${ }^{4}$ Intentionally defaulting on two bonds even though it had the cash reserves to service them, the Ecuadoran government forced a restructuring of its public debt and successful debt relief. Due to the global financial crisis at the time it was able to repurchase these bonds a discounted rate and by 2014 was issuing bonds again (Feibelman, 2017, p. 48).
} 
relieve the over $\$ 130$ billion debt that saddled Iraq after the defeat of Saddam Hussein, few countries, including Iraq, have resorted to the doctrine due to fear that it will damage their reputations and therefore prevent them from securing future loans (Brown, 2015; Wong, 2012). In addition creditors have been willing to find alternative paths to debt relief that they can control and that do not hold them legally accountable for their lending practices, such as significant restructuring programs that guarantee they will be at least partially compensated.

Challenging the authority of creditors is precisely why odious debt deserves fuller consideration. Rather than solely blaming debtors for their insolvency, the doctrine of odious debt demands a deliberate interrogation of the motives and practices of lenders and should force international law to recognize that lenders have responsibilities. The actions of creditors often escape scrutiny, which is hardly surprising given their power and wealth. The neoliberal lending policies of international organizations like the IMF and corporate financial institutions frequently protect the interests of creditors at the expense of debtors (Graeber, 2014). This has positioned debtors with the burden of responsibility for paying back loans even if lenders have acted unscrupulously or if debtors had inadequate knowledge of repayment conditions. Critics argue that these policies have diverted public debt from funding social investments, like education, healthcare and public sector jobs, and turned it into a "subsidy program to increase the power of the private sector" (Dienst, 2011, p. 59). Taxpayers are obliged to pay the costs of repayment at the expense of state services that should benefit them. Perhaps most indicative of the power of creditors is that even the poor "must pay interest to creditors through the reimbursement of public debt" (Lazzarato, 2012, p. 32).

Of course, borrowers can act imprudently as well and should be held accountable for debt they accrue from reckless spending or risky financial decision-making. But, given their lack of power in relation to creditors, the onus of due diligence should be shouldered by creditors as the doctrine of odious debt implies (Chasaide, 2012). This standard especially should apply to cases like Puerto Rico where citizens face austerity measures and higher taxes to pay back debt that was accumulated in their name without their direct consent or knowledge. Undoubtedly, offshore lenders - particularly predatory hedge funds - were cognizant of the dire financial situation on the island when they purchased portions of Puerto Rico's public debt, especially after bonds were downgraded to junk status (Klein, 2018). According to PradosRodríguez (2019) "many of the investors who own Puerto Rico's debt, including vulture hedge funds, never expected the island to be able to repay all of it because it had already been written down as bad debt - which is what allowed these investors to buy it at steep discounts on the secondary market" (p. 252). Hedge fund speculators were aware that Puerto Rico could not declare bankruptcy, betting that this "would yield a higher return once it defaulted" (Morales, 2019b, p. 220). 
Bannan (2016) and Dimitriu (2015) argue that odious debt is not just a legal issue, but a moral issue and a matter of justice if people who do not benefit from public debt are required to pay it back at the expense of their own wellbeing or if it violates their human rights. According to Bannan, this means that the odious debt doctrine should apply to the case of Puerto Rico:

Various principles in international law contribute to the formation of the notion of odious debt, all of which are applicable in the context of Puerto Rico. Strict interpretation and compliance with traditional contract law and creditor/debtor lending principles shifts to more equitable considerations under the doctrine of odious debt. Such considerations include promoting equitable and fair dealing, protecting human rights, establishing and supporting democracy and democratic movements, and creating processes for true civic participation. (Bannan, 2016, p. 291)

Bannan (2019) further explains that predatory lending practices should be taken into account when determining if (and how much) public debt be deemed odious, including unfair interest rates and failure of lenders to restructure or adjust loan conditions when borrowers face unanticipated circumstances, such as Hurricane Maria in the case of Puerto Rico (p. 229).

Federal government policies that have favored the interests of the political and financial elite - and ignored the wellbeing of residents - should also be considered when determining if (and how much of) Puerto Rico's public debt is odious. This should include the history of Puerto Rico's status as a colony and unequal territory of the US mainland. Morales (2019b) argues that Puerto Rico's debt was caused "primarily by its colonial relationship with the United States," which "used it as a laboratory for unfettered capitalism" (p. 212). Bannan (2019) concurs, asserting that "there is nothing more odious than being a colony" (p. 231). Federal tax policies that caused deindustrialization and a resultant increase in unemployment and public debt need to be taken into account (Caraballo-Cueto \& Lara, 2018). So too should legislation, like the 1917 Jones Act, that has forced Puerto Ricans to endure higher prices for food and other goods due to protectionist US maritime regulations (Grabow, 2019). ${ }^{5}$ By treating Puerto Ricans as separate and unequal citizens and supporting economic policies that have trapped the island as a periphery of the mainland, the US federal government should be held at least partially

\footnotetext{
${ }^{5}$ The Jones Act stipulates that domestic water transport must be conducted by vessels made in the US, manned by US crews, and owned by a US entity. Two recent studies have demonstrated that the Jones Act increases the price of goods in Puerto Rico. Advantage Business Consulting (2019) found that it added a cost of $\$ 367$ million for food and beverages, or what amounts to a tax of $7.2 \%$ on these goods. John Dunham \& Associates (2019) examined the shipping costs of 260 commodities and found that the Jones Act increased the cost of shipping to Puerto Rico by almost $\$ 569$ million and increased prices by $\$ 1.1$ billion (Grabow, 2019). This study also found that it has prevented the creation of 13,250 jobs and accounted for $\$ 337$ in million in lost wages and \$106 million in lost tax revenue (Helton, 2019).
} 
responsible for its public debt. But, how can Puerto Ricans "establish objective grounds for selective repudiation of odious debt" (Boyce \& Ndikumana, 2012, p. 36)? One answer may be by conducting a CPDA.

\section{Accounting for Justice via Citizen Public Debt Audits}

If citizens of indebted states are subjected to repaying what they consider odious debt, they can attempt to prove it and hold lenders and/or other parties responsible for this debt via a citizen public debt audit (CPDA) (Bannan, 2019; Fattorelli, 2013). A CPDA is a key tactic that can be used to make public debt legible to lenders and borrowers, creditors and debtors. Compared to campaigns that aim for debt forgiveness, which typically situate debtors not creditors - as the primary actors at fault, a CPDA frames debt as a matter of justice and aims to hold creditors accountable for their lending practices. It also requires the direct participation of debtors, which past efforts of debt forgiveness or cancelation, such as Jubilee 2000, failed to do. ${ }^{6}$ Thus, as a matter of justice a CPDA aims to determine not just "who picks up the tab" but constitutes a "struggle for democracy" (Dearden, 2011, p. 8). A CPDA requires the extensive participation of those who bear the burden of debt obligations even if they have not been the main beneficiaries of debt accrual. Fattorelli (2018) argues that since the "general population pays a country's public debt - through heavy tax burdens and the inadequacy of public service - citizen participation in debt audits is essential" (p. 478). Therefore, a CPDA operates not just an as instrument of legibility, but of mobilization as well.

As an instrument of legibility a CPDA is an analytic strategy that subalterns can appropriate to reconstruct governance and accountability structures, such as the case of Ceylon Tea (Alawattage \& Wickramasinghe, 2008). A CPDA adopts a professional accounting tool - the audit - and exercises the quantitative language of numbers that creditors and governments understand and venerate as a legitimate form of knowledge. Gray et al. (2014) explain that, broadly understood, accounting is a "practice of control and surveillance," but that it has an emancipatory potential if it can be used to control and survey "the powerful on behalf of the oppressed and dispossessed" (p. 282). Historically, debtors - and other subjects with little or no leverage - have been victimized by this language and knowledge via the threat or use of violence. Accounting practices (and practitioners) have been employed by repressive governments to annihilate, subjugate, exploit, and exclude populations, including Jewish people during the Holocaust and Canada's First Nations communities (Funnell \& Walker, 2013; Lippman \&

\footnotetext{
${ }^{6}$ Jubilee 2000 was a global campaign organized by faith-based groups, celebrities, academics, and other activists in the global North to pressure Western countries to cancel the debt of heavily indebted poor countries in the global South (Mayo, 2005; Pettifor, 2006). In exchange for debt relief these countries were obliged to allocate money that would have been used to service their public debt on domestic poverty reduction programs.
} 
Wilson, 2013; Walker, 2013). A CPDA offers debtors (and accountants that represent their interests) a means to use the language and therefore power of creditors to their advantage by specifically recording "who really owes what to whom" (Graeber, 2014, pp. 13-14).

Unlike a conventional audit, an ideal CPDA aims "to calculate the human effects of debt" (Graeber, 2014, p. 13) and therefore accounts for not only financial debt, but social, environmental, and other types of debt as well. As such a CPDA constitutes a form of social accounting. Financial accounting makes only certain kinds of transactions legible, while social accounting attempts to make transparent the costs of inequality, such as the lived experiences of citizens who endure austerity or suffer from human rights violations and the costs of environmental degradation (Gray et al., 2014; Han, 2012). Spence (2009) explains that "the basic argument underlying the social accounting project is that organisations have a duty to discharge information pertaining to their social and environmental interactions to a wider group of constituents than simply financial stakeholders" (p. 206).

While early efforts of social accounting primarily pressured corporations to voluntarily provide this information in the spirit of transparency, more radical practices emerged from city governments and civil society organizations that hoped to develop its emancipatory potential, including social audits (Owen et al., 2000; Spence, 2009). While many of these continue to focus on corporate responsibility (or the lack thereof), others are scrutinizing the behavior of governments. For example, city councils in Newcastle and Sheffield initiated social audits in the mid-1980s to account for how government policies were worsening local living conditions (Owen et al., 2000, p. 83). Employing a Marxist framework, Cooper et al. (2005) produced a social audit on the parttime working experiences of full-time students at three Glasgow Universities to expose the hidden costs of raising tuition fees, such as increased psychological stress, insensitive employers, missed lectures, and poor grades. Their findings were submitted to and included in the Cubie Report, a document produced by a governmental enquiry into student financing and cited in several Scottish newspapers. Using a social audit to try to change public policy exemplifies how social accounting can "go beyond a narrow instrumentalism towards an appreciation, informed by critical reflection, of 'what really matters' to people, including the governance of social relations" (Gallhofer \& Haslam, 2002, p. 105).

Cooper et al. (2005) stress that change is most likely to be realized if social accounting is "articulated to social movements" (p. 955; emphasis in original). This is precisely what a CPDA entails, in addition to actually mobilizing ordinary individuals to help conduct the audit. CPDA extends the logic of social accounting and the tactic of a social audit from an instrument of legibility conducted by professionals into an instrument of mobilization. As a mobilizing tactic a CPDA should be recognized as an "emancipatory praxis" that empowers citizens (Peden, 2019) and a potential "tool of social 
transformation" (Malinen, 2015). Hughes (2019, p. 487) describes a CPDA as a type of a-legal strategy because it occupies "an alternative legal space" that helps "to illuminate... not only what we ought to do, but what we can do: what we are empowered through the law to make happened." Fundamentally, a CPDA means questioning the morality - and the official "austerity narrative" (Malinen, 2015) - that debts must always be repaid (Graeber, 2014; Toussaint \& Millet, 2012). This questioning requires engaging citizens who are being held responsible for public debt in a participatory process that makes the origins and effects of this debt transparent. Critically, this process necessitates the gathering and dissemination of information about public debt from the government, private creditors, and any other actors that have a record of how it was accrued and spent. In addition raising awareness about the purpose of a CPDA and collecting funds to conduct the audit are required to make a CPDA a successful mobilizing tactic (Fattorelli, 2018). Fattorelli (2018) describes how this worked in Brazil with its CPDA, including staging public events, holding seminars, recovering historical documents, creating a distance learning course, maintaining a social media presence, and publishing documents.

The citizens of Spain engaged many of these ideas and actions to initiate a public debt audit. ${ }^{7}$ On 15 May 2011 millions of citizens staged protests to fight austerity measures that were enacted by the government to pay down debt it had incurred as a consequence of the 2008 Recession. This aptly named 15M movement provided the impetus for the Citizen Debt Audit Platform (PACD) in 2012 to continue the struggle against illegitimate debt and realize the precedent of "we don't owe, we don't pay." Notably, PACD provided the impetus for anti-debt activists and the tactic of the CPDA to enter mainstream politics, especially in municipalities where social progressives won council seats in the 2015 elections. Municipal citizen observation groups were organized to monitor city expenditures, fight neoliberal budget cuts that aimed to privatize more social services, and check the power of financial institutions. Though this so-called "municipalist" movement lost some cities in later elections and ceded to a centralized economic plan that prioritized debt repayments over public investment and expenditure, it helped to popularize public debt audits and provide lessons for future organizers, such as maintaining stronger collaboration across municipalities (Álvarez Balba, 2020; Fresnillo, 2019; Malinen, 2016). Similar lessons can be learned from the strengths and shortcomings of the 2011 Greek Debt Audit Campaign and the Truth Commission on Greek Debt, such as the difficulties working with newly elected politicians and political parties, like Alexis Tsipras and Syriza, which promise to repudiate debt and reject austerity but fail to deliver (Kouvaras, 2018; Laskaridis et al., 2020).

\footnotetext{
${ }^{7}$ Citizens have initiated public debt audits in many different countries. For more information see the Committee for the Abolition of Illegitimate Debt at https://www.cadtm.org/.
} 
It is important to note that CPDAs may be initiated by or involve the support of governments. This was the case of one of the most successful public debt audits, which occurred in Ecuador in 2007. The Ecuadorian government established a national debt audit commission to examine debt that it incurred from 1976 to 2006, noting not just economic costs, but also social and environmental damages. Commercial loans from private banks, bilateral loans from other nations, and multilateral loans from the IMF and World Bank were all scrutinized from the perspective of holding creditors accountable for unjust and even illegal debt that hurt rather than helped the people of Ecuador. The final audit report outlined a number of questionable loans, including two global bonds worth approximately $\$ 3$ billion that the Ecuadorian government deemed illegitimate and repudiated via a default. Commercial banks that held these bonds agreed to allow the Ecuadorian government to repurchase these bonds at approximately $35 \%$ of their face value, or $\$ 900$ million, saving the government about $\$ 300$ million in future annual interest payments (Economist, 2009). What makes this case of debt resistance most remarkable is that Ecuador had enough capital to service its foreign debt; however it used its audit findings to document how doing so would not be in the best interests of its people (Feibelman, 2017). As stated in the executive summary of this report: "the public debt... undoubtedly has resulted in the brake imposed on the development and the disillusionment of Ecuadorians, whose reality is far from the basic conditions of the good life" (Integral Auditing Commission for Public Credit of Ecuador, 2008). While Ecuador's debt audit did not justify eradicating all of its external debt, it did succeed in holding its creditors accountable for about one-third of it (“Ecuador's Winning Strategy", 2009).

\section{Puerto Rico's CPDA}

Similar to the case of Ecuador the Puerto Rican government authorized a public debt audit commission in 2015 to investigate over 40 years of government bond transactions. The commission consisted of 17 members representing a variety of civil society sectors, including labor, education, public health, public housing and the environment. Its initial findings discovered that many of the bonds sold to investors since 2006 violated Puerto Rico's constitutional debt ceiling and public disclosure requirements. However, the commission was legally repealed in 2017 by Puerto Rico's governor Ricardo Roselló, who argued it was an "unnecessary expense" and that any debt deemed illegal would need to be decided in the courts, not by a commission (Ortiz, 2017).

Many Puerto Ricans were displeased about this commission being disbanded, so they created their own organization to continue the work of auditing the island's public debt. Currently the Citizen Commission for the 
Comprehensive Audit of the Public Debt (Comisión Ciudadana para la Auditoría Integral del Crédito Público) created by a coalition of citizens called the Citizen Front for the Debt Audit (Frente Ciudadano por la Auditoría de la Deuda), is planning to conduct a comprehensive, integral audit of Puerto Rico's public debt over the past 50 years (Prados-Rodríguez, 2019; Its key audit standards include: (1) legality: to verify public debt is in compliance with the law; (2) quantity: verify the total sum of public debt; and (3) guarantees: to discover mechanisms to prevent excessive debt in the future. The audit is planned to include four "investigative processes," including a financial audit that will determine how much is owed, a forensic audit that will determine the legality of bonds that were issued, a compliance audit that will evaluate the behavior of all actors involved, in particular the government and financial institutions, and a performance audit that will evaluate how the money from bond sales was spent. Additionally, it has outlined six distinct phases of the entire audit process: (1) Planning, Recruitment, and Monitoring; (2) Initial Evaluation and Risk Assessment; (3) Implementation; (4) Writing and Presenting Results; (5) Ongoing Work; (6) Post-audit (Una Auditoría Ciudadana, n.d.). Of course, financial resources are needed in order to accomplish this audit. The Citizen Commission for the Comprehensive Audit of the Public Debt estimates it will need $\$ 500,000$ for phase one and \$5.6 million to complete the entire audit process. Auditoría Ya is attempting to procure some of this money via crowdfunding on its webpage (Una Auditoría Ciudadana, n.d.), and has raised just over $\$ 44,700$ so far.

The Citizen Front to Audit the Debt in Puerto Rico has pursued a variety of actions to raise awareness about public debt and the Puerto Rican CPDA, including teach-ins, street protests, open data sources, online message boards, and painting murals in public spaces. It is also trying to persuade the Puerto Rican government to share its knowledge of public debt with its citizens, including releasing public records. While the government has provided this information to its bondholders and FOMB, it has not been so forthcoming with the Citizen Commission. Currently, the Citizen Commission is suing the government to obtain access to the public records it needs to conduct its CPDA (Prados-Rodríguez, 2019, p. 254). In the words of Toussaint and Millet (2012) "real transparency is the ruling classes' worst nightmare." which is likely the reason these records and other documentation are being withheld. Remarkably, FOMB has become an unlikely ally in the effort to annul a portion of Puerto Rico's public debt. In 2019 the board asked the courts to invalidate \$6 billion worth of GO bonds issued in 2012 and 2014 (mostly to hedge funds) because they violated Puerto Rico's constitutional debt ceiling (Acevedo \& Associated Press, 2019). The board is also working with Puerto Rico Electric Power Authority bondholders and Assured Guaranty Corp. to reduce the utility's debt up to $32.5 \%$; however, a stipulation of this arrangement will require customers to pay more per kilowatt hour (a maximum rate of 4.552 cents) at the same time the utility is being privatized (Ortiz, 2019). Most recently, FOMB reached a tentative 
agreement with Puerto Rico creditors to settle $\$ 35$ billion in public debt. Bondholders, including Aurelius Capital Management and other hedge funds, that threaten to sue Puerto Rico in court for full repayment of all bonds, have agreed to partial reimbursement at 74.9 cents, 69.9 cents and 65.4 cents on the dollar depending on the vintage of the bonds they hold (Walsh, 2020). ${ }^{8}$

Though these efforts by FOMB to reduce the public debt in Puerto Rico are a step forward, they are neither democratically participatory nor comprehensive like a CPDA. Citizens are being compelled, not asked, to pay higher electricity rates and higher taxes to fund a portion of the CONIFA debt restructuring plans, the terms of which remain questionable until the courts give final approval. Furthermore, creditors are retaining much of their leverage and recouping a substantial share of their investments without admitting any culpability for the public debt crisis. Unlike a comprehensive CPDA, FOMB debt restructuring has yet to entail the transcription of social and ecological debt, and its investigation of financial debt lacks historical insight. According to Morales (2019b) the island's "dubious territorial status" has situated it as a "captive for decades of austerity and severe exploitation" (p. 221). Among the many debts that creditors and the federal government could be held accountable for include policies and legislation that have favored the profits of US corporations over the wellbeing of Puerto Ricans and their environment, like:

- the 1917 Jones Act, which has resulted in a loss of tax revenue on the sale of government bonds, higher consumer prices, increased unemployment, and lower wages (Advantage Business Consulting, 2019; John Dunham \& Associates, 2019);

- taxation policies during the early 1900s that resulted in the loss of land ownership and access to arable land for middle and lower-income residents in addition to tariff exemptions from sugar imports that "facilitated the dominance of US sugar trusts" (Fusté, 2017, p. 100);

- test subjects for dangerous drugs for the US pharmaceutical industry (Klein, 2018, p. 25);

- unemployment and mass outmigration caused by the repeal of Section 936;

- poor health caused by an underfunded Medicaid program;

- mental health problems caused by the inadequate emergency response and recovery initiatives from Hurricanes Irma and Maria, including lack of electricity, clean water, food, and housing;

- environmental contamination caused by the US military testing chemicals, like napalm, and agribusinesses testing genetically modified seeds (Klein, 2018, p. 26).

\footnotetext{
${ }^{8}$ These dollar amounts are substantially higher than initial restructuring terms, which were at 64 cents, 45 cents, and 35 cents on the dollar (Walsh, 2020).
} 
Undoubtedly, it will be a challenge to frame many if not all of these issues as "objective grounds" for debt repudiation under the doctrine of odious debt (Boyce \& Ndikumana, 2012, p. 36). However, they capture the history of the social and environmental costs that constitute the peculiar nature of Puerto Ricans public debt, and the legacy of colonialism that residents continue to endure (Morales, 2019a).

\section{Conclusion}

Accounting for social and environmental debt is but one of many challenges associated with a citizen public debt audit that Puerto Ricans will likely encounter. As mentioned earlier raising funds to pay for the audit is necessary, yet may be difficult given the financial insecurity of many who would be most likely to support it. Dealing with corrupt political leaders and an unstable government poses a myriad of problems as well, especially guaranteeing long-term commitments in regards debt repudiation or even restructuring. Other obstacles include access to public records, which governments may try to block by rescinding freedom of information protocols and finding experts to help decode intentionally "opaque" financial instruments designed to protect creditors (Malinen, 2015). However, as an emancipatory praxis a CPDA has the potential to generate social change by educating Puerto Ricans about the causes and consequence of public debt and including them in economic and public policy decision-making. Attending teach-ins, organizing street protests, networking via social media, and fundraising online can provide a foundation for a participatory form of democracy that, in the case of Puerto Rico, could conceivably determine the future territorial status of the island. Whether or not Puerto Ricans vote to become an independent country, the fifty-first state of the US, or remain an unincorporated territory, their involvement with a CPDA can enable them to build connections with each other and provide the proficiencies for them to help oversee and manage the island's budget when FOMB is eventually dissolved. Indeed, the knowledge and experience gained from participation in a citizen public debt audit has the potential to "deepen democracy" and encourage "empowered participatory governance" in Puerto Rico and other sites of indebtedness (Fung \& Wright, 2001, p. 5).

\section{References}

Acevedo, N., \& Associated Press. (2019, January 15). Billions of Puerto Rico's debt might be invalid, federal oversight board says. NBC News. https://www.nbcnews.com/news/latino/billions-puerto-rico-s-debt-might-be-invalidfederal-oversight-n958846

Advantage Business Consulting. (2019, February 25). Analysis of issues related to maritime transportation to Puerto Rico. Washington International Trade Association. 
https://www.wita.org/atp-research/analysis-of-issues-related-to-maritime-transportation-topuerto-rico/

Alawattage, C., \& Wickramasinghe, D. (2008). Weapons of the weak: Subalterns' emancipatory accounting in Ceylon Tea. Accounting, Auditing, \& Accountability Journal, 22(3), 379-404.

Álvarez Balba, Y. (2020, June 25). Debt: The straightjacket on municipalism. European Network of Corporate Observatories. https://corpwatchers.eu/en/investigations/cities-versusmultinationals/debt-the-straightjacket-on-municipalism

Bannan, N. L. O. (2016). Puerto Rico's odious debt: The economic crisis of colonialism. City University of New York Law Review, 19(2), 287-311.

Bannan, N. L. O. (2019). Puerto Rico's debt is odious. In Y. Bonilla \& M. LeBrón (Eds.), Aftershocks of disaster: Puerto Rico before and after the storm. Haymarket Books.

Boyce, J., \& Ndikumana, L. (2012). Debt audits and the repudiation of odious debt. Association of Concerned African Scholars, 87, 36-41.

Brown, V. (2015). Note: Felonious, erroneous, it's all odious: A story of debt gone wrong. Fordham Law Review, 84(2), 725-767.

Caraballo-Cueto, J., \& Juan, L. (2018). Deindustrialization and the unsustainable debt in middleincome countries: The case of Puerto Rico. Journal of Globalization and Development, $8(2), 1-11$.

Chasaide, N. N. (2012). From debt audits to debt justice: Drawing lessons from the Global South in development education in Ireland. Policy \& Practice: A Development Education Review, $14,33-44$.

Cooper, C., Taylor, P., Smith, N., \& Catchpowle, L. (2005). A discussion of the political potential of social accounting. Critical Perspectives in Accounting, 16(7), 951-974.

Dearden, N. (2011, November). Citizen auditors challenge euro-debt. New Internationalists, (447), 8-9.

Dienst, R. (2011). The bonds of debt. Verso.

Dimitriu, C. (2015). Odious debt: A moral account. Jurisprudence, 6(3), 470-491.

Di Muzio, T., \& Robbins, R. (2016). Debt as power. Manchester University Press.

Ecuador's winning strategy. (2009, June 17). The Economist. https://www.economist.com/news/2009/06/17/ecuadors-winning-strategy

Fattorelli, M. L. (2018). Citizen debt audits. In I. Bantekas \& C. Lumina (Eds.), Sovereign debt and human rights (pp. 477-497). Oxford University Press.

Feibelman, A. (2017). Ecuador's 2008-2009 debt restructuring: A special case? In J. P. Bohoslavsky \& K. Raffer (Eds.), Sovereign debt crises: What have we learned? (pp. 4864). Cambridge University Press.

Fresnillo, I. (2019, May 22). Debt: A lever of dispossession. Public Seminar. https://publicseminar.org/2019/05/debt-a-lever-of-dispossession/

Fung, A., \& Wright, E. O. (2001). Deepening democracy: Innovations in empowered participatory governance. Politics \& Society, 29(1), 5-41.

Funnell, W., \& Walker, S. (2013). Introduction. In R. Fleischman, W. Funnell, \& S. Walker (Eds.), Critical histories of accounting: Sinister inscriptions in the modern era (pp. 1-14). Routledge.

Fusté, J. I. (2017). Repeating islands of debt: Historicizing the transcolonial relationality of Puerto Rico's economic crisis. Radical History Review, 2017(128), 91-119.

Gallhofer, S., \& Haslam, J. (2002). Accounting and emancipation: Some critical interventions. Routledge.

Gluzmann, P., Guzman, M., \& Stiglitz, J. (2018). An analysis of Puerto Rico's debt relief needs to restore debt sustainability. Centro Journal, 30(3), 104-146.

Grabow, C. (2019, February 23). New reports detail the Jones Act's cost to Puerto Rico. Cato Institute. https://www.cato.org/blog/new-reports-detail-jones-acts-cost-puerto-rico

Graeber, D. (2014). Debt: The first 500 years. Melville Housing.

Gray, R., Brennan, A., \& Malpas, J. (2014). New accounts: Towards a reframing of social accounting. Accounting Forum, 38(4), 258-273. 
Greenberg, S., \& Ekins, G. (2015, June 30). Tax policy helped create Puerto Rico's fiscal crisis. Tax Foundation. https://taxfoundation.org/tax-policy-helped-create-puerto-rico-s-fiscalcrisis/

Grosfoguel, R. (2003). Colonial subjects: Puerto Ricans in a global perspective. University of California Press.

Haddad, A. (2019, July 22). Puerto Rico's health care crisis: Where empire and climate change collide. in-Training. https://in-training.org/puerto-ricos-healthcare-crisis-where-empireand-climate-change-collide- 18540

Han, C. (2012). Life in debt: Times of care and violence in neoliberal Chile. University of California Press.

Helton, J. (2019, April 22). More studies show Jones Act harmful to Puerto Rico. Grassroots Institute of Hawaii. https://www.grassrootinstitute.org/2019/04/puerto-rico-clearly-needsrelief-from-the-jones-act/

Ho, J. D. (2018, June). Puerto Rico's debt crisis: Overview. Points of View: Puerto Rico's debt crisis. Salem Press.

Hughes, C. (2019). Action between the legal and illegal: A-legality as a political-legal strategy. Social \& Legal Studies, 28(4), 470-492.

Integral Auditing Commission for Public Credit of Ecuador. (2008, December 12). Final report of the integral auditing of the Ecuadorian debt-Executive summary. http://www.cadtm.org/Final-Report-of-the-Integral

John Dunham \& Associates. (2019, February). The Jones Act: A legacy of economic ruin for Puerto Rico. https://docs.wixstatic.com/ugd/5b4228_4e79040fd1b043a59df921358825334a.pdf

Klein, N. (2018). The battle for paradise. Haymarket Books.

Ko, B. (2017). Nothing left to tax or cut, the gate to chapter 9 is shut: The Puerto Rico debt crisis. Loyola of Los Angeles Law Review, 50(2), 313-327.

Kouvaras, M. (Director). (2018). Audit: An inquiry into Greek debt [Film]. Committee for the Abolition of Illegitimate Debt \& ZinTV. https://www.cadtm.org/Film-The-Audit-AnEnquiry-into-Greek-Debt

Laskaridis, C., Legrand, N., \& Toussaint, E. (2020). Historical perspectives on current struggles against illegitimate debt. In P. Mader, D. Mertens, \& N. van der Zwan (Eds.), The Routledge handbook of financialization (pp. 482-493). Routledge Handbooks Online.

Lazzarato, M. (2012). The making of indebted man. Semiotext(e).

Lippman, E., \& Wilson, P. (2013). Accountants and the Holocaust. In R. Fleischman, W. Funnell, \& S. Walker (Eds.), Critical histories of accounting: Sinister inscriptions in the modern era (pp. 69-81). Routledge.

Lumina, C. (2018). Curbing 'vulture fund' litigation. In I. Bantekas \& C. Lumina (Eds.), Sovereign debt and human rights (pp. 498-513). Oxford University Press.

Malinen, F. (2015, December 5). Debt audits challenge power of opaque finance. openDemocracy. https://www.opendemocracy.net/en/can-europe-make-it/debt-auditschallenge-power-of-opaque-finance/

Malinen, F. (2016, November 2). Councils across Spain are working on debt audits: Report from \#AuditFest. Debt Resistance UK. http://lada.debtresistance.uk/councils-across-spainworking-debt-audits-report-auditfest/

Mayo, M. (2005). 'The world will never be the same again': Reflecting on the experiences of Jubilee 2000, Mobilizing Globally for the Remission of Unpayable Debts. Social Movement Studies, 4(2), 139-154.

Morales, E. (2016, June 7). Who is responsible for Puerto Rico's debt? The Nation. https://www.thenation.com/article/archive/who-is-responsible-for-puerto-ricos-debt/

Morales, E. (2019a). Fantasy island: Colonialism, exploitation, and betrayal in Puerto Rico. Hachette Book Group.

Morales, E. (2019b). Puerto Rico's debt is unjust. In Y. Bonilla \& M. LeBrón (Eds.), Aftershocks of disaster: Puerto Rico before and after the storm (pp. 211-223). Haymarket Books.

Ortiz, L. V. (2017, April 17). Puerto Rican government repeals commission to audit debt. Caribbean Business. https://caribbeanbusiness.com/puerto-rico-government-repealscommission-to-audit-debt/ 
Ortiz, L. V. (2019, May 3). Puerto Rico announces deal to restructure power authority debt. Reuters. https://www.reuters.com/article/us-usa-puertorico-prepa-idUKKCN1SA026

Owen, D., Swift, T., Humphrey, C., \& Bowerman, M. (2000). The new social audit: Accountability, managerial capture, or the agenda of social champions? The European Accounting Review, 9(1), 81-98.

Peden, M. (2019). Revolutionary accounting? Methods and possibilities in critical strategies. New Political Science, 41(4), 559-573.

Pettifor, A. (2006). The Jubilee 2000 Campaign: An overview”. In C. Jochnick \& F. Preston (Eds.), Sovereign debt at the crossroads (pp. 297-318). Oxford University Press.

Prados-Rodríguez, E. (2019). Puerto Rico's fight for a citizen debt audit: A strategy for public mobilization and a fair reconstruction. In Y. Bonilla \& M. LeBrón (Eds.), Aftershocks of disaster: Puerto Rico before and after the storm (pp. 250-256). Haymarket Books.

Selbst, S. (2016). Puerto Rico financial oversight law enacted. Bloomberg BNA. http://www.herrick.com/content/uploads/2016/08/8-11-16_Bloomberg-BNA-BankruptcyLaw-Reporter_Stephen-Selbst.pdf

Smith, R. (2001). The bitter roots of Puerto Rican citizenship. In C. D. Burnett \& B. Marshall (Eds.), Foreign in a domestic sense: Puerto Rico, American expansion, and the constitution (pp. 373-387). Duke University Press.

Spence, C. (2009). Social accounting's emancipatory potential: A Gramscian critique. Critical Perspectives in Accounting, 20(2), 205-227.

Streeck, W. (2014). The politics of public debt: Neoliberalism, capitalist development and the restructuring of the state. German Economic Review, 15(1), 143-165.

Torres, M. N. (2019, June 11). Puerto Rico's post-Maria Medicaid crisis. DCReport. https://www.dcreport.org/2019/06/11/puerto-ricos-post-maria-medicaid-crisis/

Toussaint, E., \& Millet, D. (2012, January 4). Citizen debt audits: How and why? Committee for the Abolition of Illegitimate Debt. www.cadtm.org/Citizen-debt-audits-how-and-why

Una Auditoría Ciudadana. Auditoria YA. (n.d.). http://www.auditoriaya.org/

Walsh, M. W. (2019, May 2). Puerto Rico seeks to have \$9 billion in debt ruled unconstitutional. New York Times. https://www.nytimes.com/2019/05/02/business/puerto-rico-debtbanks.html

Walsh, M. W. (2020, February 11). Puerto Rico reaches deal with creditors to settle $\$ 35$ billion in debt. New York Times. https://www.nytimes.com/2020/02/10/business/puerto-ricodebt.html

Weiss, A., \& Setser, B. (2019, July/August). America's forgotten colony: Ending Puerto Rico's perpetual crisis. Foreign Affairs, 98, 158-168.

Wong, Y. (2012). Sovereign finance and the poverty of nations: Odious debt in international law. Edward Elgar. 